\title{
The Impact of Species Concept on Biodiversity Studies
}

Keith A. Crandall

Paul-Michael Agapow

Olaf R. P. Bininda-Emonds

John L. Gittleman

Georgina M. Mace

See next page for additional authors

Follow this and additional works at: https://scholarsarchive.byu.edu/facpub

Part of the Biology Commons

\section{Original Publication Citation}

The Quarterly Review of Biology 79.2(Jun 24): 161-179.

\section{BYU ScholarsArchive Citation}

Crandall, Keith A.; Agapow, Paul-Michael; Bininda-Emonds, Olaf R. P.; Gittleman, John L.; Mace, Georgina M.; Marshall, Jonathon C.; and Purvis, Andy, "The Impact of Species Concept on Biodiversity Studies" (2004). Faculty Publications. 437.

https://scholarsarchive.byu.edu/facpub/437

This Peer-Reviewed Article is brought to you for free and open access by BYU ScholarsArchive. It has been accepted for inclusion in Faculty Publications by an authorized administrator of BYU ScholarsArchive. For more information, please contact ellen_amatangelo@byu.edu. 


\section{Authors}

Keith A. Crandall, Paul-Michael Agapow, Olaf R. P. Bininda-Emonds, John L. Gittleman, Georgina M. Mace, Jonathon C. Marshall, and Andy Purvis 


\title{
THE IMPACT OF SPECIES CONCEPT ON BIODIVERSITY STUDIES
}

\author{
Paul-Michael Agapow \\ Department of Biology, University College London \\ Darwin Building, Gower Street, London WC1E 6BT United Kingdom \\ E-MAIL: P.AGAPOW@UCL.AC.UK \\ Olaf R. P. Bininda-EMONDS* \\ Institute of Evolutionary and Ecological Sciences, Leiden University \\ Kaiserstraat 63, P.O. Box 9516, 2300 RA Leiden, The Netherlands
}

Keith A. Crandall

Department of Zoology, Brigham Young University

Provo, Utah 84602 USA

John L. GitTleman

Department of Biology, University of Virginia

Gilmer Hall, Charlottesville, Virginia 22903 USA

Georgina M. Mace

Institute of Zoology, The Zoological Society of London

Regent's Park, London NW1 4RY United Kingdom

Jonathon C. Marshall

Department of Zoology, Brigham Young University

Provo, Utah 84602 USA

\section{Andy Purvis}

Department of Biological Sciences, Imperial College

Ascot, Berks SL5 7PY United Kingdom

*Present address: Lehrstuhl für Tierzucht, Technical University of Munich, Alte Akademie 12, 85354 FreisingWeihenstephan, Germany.

The Quarterly Review of Biology, June 2004, Vol. 79, No. 2

Copyright (C) 2004 by The University of Chicago. All rights reserved.

0033-5770/2004/7902-0002\$15.00 
KEYWORDS

conservation, biodiversity, extinction, species concept

ABSTRACT

Species are defined using a variety of different operational techniques. While discussion of the various methodologies has previously been restricted mostly to taxonomists, the demarcation of species is also crucial for conservation biology. Unfortunately, different methods of diagnosing species can arrive at different entities. Most prominently, it is widely thought that use of a phylogenetic species concept may lead to recognition of a far greater number of much less inclusive units. As a result, studies of the same group of organisms can produce not only different species identities but also different species range and number of individuals. To assess the impact of different definitions on conservation issues, we collected instances from the literature where a group of organisms was categorized both under phylogenetic and nonphylogenetic concepts. Our results show a marked difference, with surveys based on a phylogenetic species concept showing more species (48\%) and an associated decrease in population size and range. We discuss the serious consequences of this trend for conservation, including an apparent change in the number of endangered species, potential political fallout, and the difficulty of deciding what should be conserved.

$S^{p}$ PECIES ARE THE currency of biology. In particular, reactions to the ongoing biodiversity crisis are ubiquitously phrased in terms of species. Areas of importance (e.g., biodiversity hotspots) are selected on the basis of the species they possess, conservation schemes are assessed on how many species are preserved, lists are compiled of endangered species and the factors that threaten them, and conservation legislation and politics are focused on species preservation (Mann and Plummer 1992; Collar et al. 1994; Baillie and Groombridge 1996; Karl and Bowen 1999; Soltis and Gitzendanner 1999).

Despite this importance, the very term "species" is deeply ambiguous. While biologists customarily treat species as tangible entities-at least more so than any other sub- or supraspecific group (Hendey 1964; Ereshefsky 1999) — there is nonetheless a vast spectrum of meanings attached to the word. The argument over how species should be defined is endless, with over twenty species concepts in circulation at present (Mayden 1997). These concepts encompass many operational and empirical definitions, often resulting in a given group of organisms being viewed in drastically different ways by different workers (Mallet and Willmott 2003).

The potential taxonomic conflicts posed by the use of different definitions for the term "species" are not just questions of semantics or miscommunication. Consensus on issues of species richness or biodiversity hotspots is difficult if no agreement can be reached on the actual identity of the species involved (Kartesz 1994). It is therefore necessary to survey the use of opposing concepts in the literature and, without promoting or deprecating any particular concept, determine the extent to which different methodologies will arrive at different boundaries and discuss the implications for the practice of biodiversity studies.

\section{Nonphylogenetic Species Concepts}

The concept of species has been well discussed in the literature; for recent reviews, see Claridge et al. 1997, Wheeler and Meier 2000, Hey 2001, and Mallet 2001. The main problem for biodiversity studies has been the gap between theory and practice. Driven by a desire for a universal and objective definition of species, a large number of ideal-centered concepts have been formulated and compete for acceptance (e.g., Van Valen 1976; Wiley 1978). The overwhelmingly dominant of these is the biological species concept (BSC) (Mayr 1942), in which species are defined as populations that cannot interbreed successfully. Species therefore are necessarily reproductively isolated, representing separate evolutionary lineages. A large part of the BSC's appeal is that proposed species boundaries are falsifiable by the natural (and substantial) production of fertile hybrids across them. 
The BSC is simple, obvious, and ultimately flawed.

Outside of ideals of the BSC, discerning potential reproductive barriers can be difficult, time consuming, expensive, and fraught with error. For example, the populations in question may be allopatric, the organisms may be both difficult to observe in the wild and difficult to raise in the laboratory (Taylor et al. 1999), or the genetic component unclear (Kullander 1999). The creatures may also be extinct or only characterized from preserved material (Claridge et al. 1997). For asexual organisms, the biological concept is simply inapplicable (Ghiselin 1987). Also, the BSC encounters difficulties where hybridization is taking place (e.g., in many plants) (Donoghue 1985). It is possible to stand by a strict interpretation of the BSC and argue that the above "exceptional" populations are, by definition, not species (Ghiselin 1987), but this leaves a vast number of organisms with a nebulous status. The BSC can illuminate only a small fragment of the Tree of Life.

Such problems are typical among the idealbased definitions. In a conservation context, more operational methods (concerned with how a species may be delimited rather than what it represents) are a necessity (Sites and Crandall 1997). These have often employed the proxy of a phenotypic definition, where species are delineated by overall, usually morphological, similarity ("morpho-species"). Yet even this most basic of approaches has problems. There is a large element of subjectivity involved (e.g., what constitutes a reasonable character, what degree of difference equates to the species level). Morphological classification can be confounded by convergent evolution, morphological simplicity (Klautau et al. 1999), ring species (Mayr 1963), natural intraspecies variation (e.g., sexual dimorphism or polymorphism), morphologically cryptic species (Ameziane and Roux 1997), and phenotypic plasticity (Mishler 1985).

Such confusion would seem to render the word "species" meaningless. In reality, most biologists hold a similar, intuitive idea of what a species represents: a population on an autonomous historical trajectory. The different methods of defining species will sometimes arrive at different answers, but if they are all measurements of essentially the same underlying entity, then comparison between studies is not unreasonable. Also, taxonomic arguments are usually concerned not with the number of species but whether organisms in a sample are or are not members of the same species (Mayden 1997). The preeminence in the field of the biological and morphological concepts makes comparison even easier, and within major groups there is often a commonality among working taxonomists about the degree of morphological difference that corresponds to a biological species boundary (Erwin and Anstey 1995; O'Keefe and Sander 1999).

\section{The Phylogenetic Species Concept}

With the advance of molecular phylogenetics and the increasing popularity of the phylogenetic species concept (PSC), the species debate has rekindled. Although the PSC has a spectrum of definitions (e.g., Mishler and Budd 1990; Nixon and Wheeler 1990; Davis and Nixon 1992), it is commonly taken to define a species as a group of organisms that share at least one uniquely derived character (Nixon and Wheeler 1990; for reviews see Wheeler and Meier 2000), perhaps with a shared pattern of ancestry and descent (Cracraft 1983) or monophyly (Donoghue 1985; de Quieroz and Donoghue 1988, 1990). The PSC is more widely applicable in practice than previous species concepts because it can be applied to asexual organisms and allopatric populations. Furthermore, it has been argued that the PSC is more objective, may reveal morphologically unremarkable but important populations, and is a better indicator of biodiversity and conservation worth of a population than other measures (Soltis and Gitzendanner 1999).

Thus, for the biodiversity researcher, the PSC is potentially useful. A more debatable point is to what extent species assessments under the PSC will concur with those made under other criteria. Species boundaries previously established from fossils are unlikely to change, as most fossil taxa are sampled too poorly for geographic variation to cause the inference of new species, and may be slightly inflated anyway due to the uncertainty of 
how much intraspecific variation (e.g., sexual dimorphism) exists. In the case of contemporaneous taxa, it could be reasoned that the various definitions of species might be expected to more-or-less agree on actual species boundaries. The character-based interpretation of the PSC has some congruence with morpho-species and the history-based version with biological and evolutionary concepts. Indeed, it has been argued that the species boundaries defined by PSC should be similar to those found by other methods, on the basis that isolated populations should differ in at least the character responsible for sympatric isolation (Knowlton and Weigt 1997; Geiser et al. 1998; Avise and Walker 1999).

Conversely, there are reasons why different species concepts will arrive at different species. It has been argued that the BSC and PSC are detecting fundamentally different entities at different stages along the speciation trajectory (Harrison 1998). Furthermore, within the PSC there is no privileged phylogenetic level that corresponds to a species other than "the smallest aggregate" (Horvath 1997). This makes the degree of taxonomic resolution sensitive to sampling effort (Sites and Crandall 1997; Walsh 2000) and could cast subspecies or, in the extreme, even individual organisms as species (Amadon and Short 1992). In contrast to this "splitting," it could be argued that the BSC overemphasizes potential gene flow between populations (Templeton 1989; Harrison 1998) and will "lump" species together. Finally, many phylogenies of species are in reality phylogenies of genes. The evolutionary history of a species and its genes may not match due to gene duplication or loss, horizontal transfer, or incomplete gene sorting (Slowinski and Page 1999; Mindell and Meyer 2001). Thus, it is widely recognized that the PSC will often split a species determined under nonphylogenetic criteria with two or more "new" species (Corbet 1997; Cracraft 1997; Knowlton and Weigt 1997). The increasing use of the PSC could thus lead to an apparent increase in extant species numbers, producing "new" groups with more restricted geographic ranges and decreased abundance. To what extent this will occur, and its potential impact on conser- vation biology and management decisions, is examined below.

\section{Comparing Phylogenetic and Nonphylogenetic Species}

We surveyed the primary literature, searching for instances of sets of organisms that had been classified by both the PSC and other means. Typically, these examples involved studies where researchers reevaluated the taxonomy of a group using a phylogenetic approach with either molecular and/or morphological data, whose species were formerly defined using either a biological species concept or a morphological surrogate of that concept. In total we reviewed 89 studies, examining changes both in the number of species and in the identity of groups; i.e., whether the "new" species nested within the boundaries of the old, fell across the old boundaries, or merged several "old" groups (Figure 1). The results are summarized in Table 1 . A wide variety of taxa from many different environments were included in our survey, but it should be emphasized that the selection is limited by the availability of data that compare the status of the taxa under the competing concepts. Thus, despite their prevalence and conservation importance, there is a relative paucity of suitable studies on insects and amphibians.

In total, the studies covered between 1245 and 1282 non-PSC-based species, which on reanalysis gave rise to between 1912 and 2112 PSC-based species, an increase of $48.7 \%$. (In this and all further analyses, if a span of species numbers is recorded, any change or difference is reported as the smallest possible within that range.) Across studies, the average number of species in a group increased by $121.0 \%$. The increase in group size was assessed with a sign test to be significant, with $p<.0001$ ( $z$ value of 6.20 ). Given that a number of studies overlap in the taxa studied, notably the vertebrate-wide survey (Avise and Walker 1999) and the birds of paradise studies (Cracraft 1992; Collar 1997), these numbers might be distorted by a small number of atypical taxa. However, even if all such studies are excluded, the increase in species numbers is $60.3 \%$, and the average increase per study is $118.3 \%$. The increase was significant with 


\section{$\underline{\text { Morpho/Biological Species }}$}
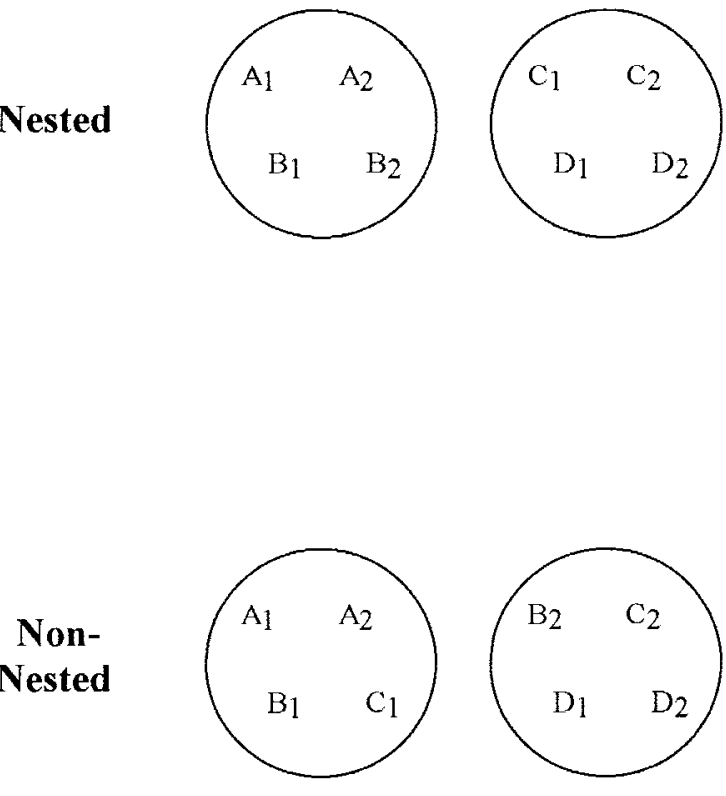

NonNested

Nested

$\mathrm{PSC}_{1}$

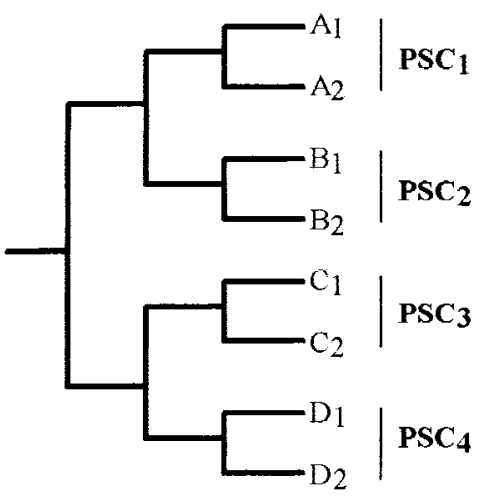

$\mathrm{PSC}_{1}$

$\mathrm{PSC}_{2}$

$\mathrm{PSC}_{3}$

$\mathrm{PSC}_{4}$

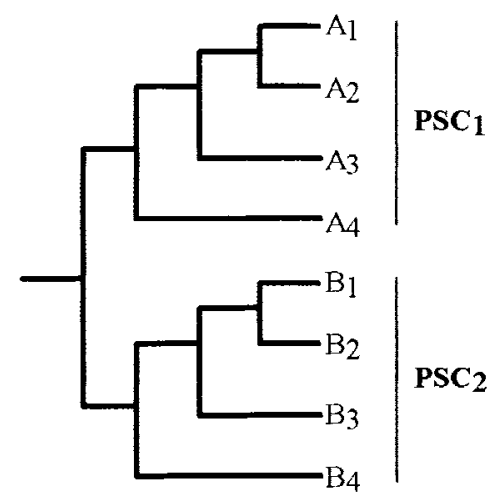

Reverse-
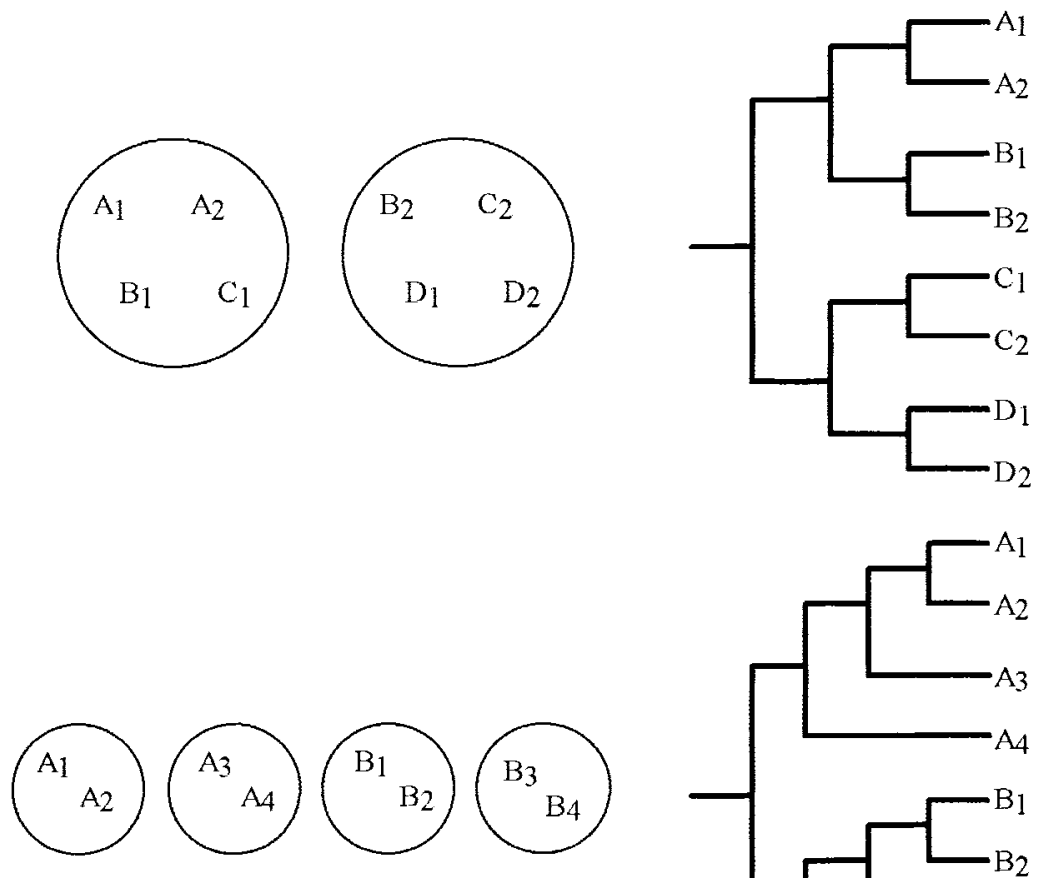

$\mathrm{PSC}_{3}$ Nesting
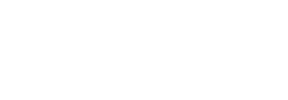

\section{Phylogenetic Species}


TABLE 1

Comparing nonphylogenetic and phylogenetic species

\begin{tabular}{|c|c|c|c|c|c|}
\hline Organisms & Region & $\begin{array}{c}\text { Species } \\
\text { (non-PSC) }\end{array}$ & $\begin{array}{c}\text { Species } \\
\text { (PSC) }\end{array}$ & Nested? & Reference \\
\hline \multicolumn{6}{|c|}{ Plants } \\
\hline $\begin{array}{l}\text { Three-seeded mercury } \\
\text { (Acalypha rhomboidea) }\end{array}$ & North America & 1 & 2 & Yes & 1 \\
\hline $\operatorname{Grass}($ Leptochloa $)$ & Global & 45 & 32 & No & 2 \\
\hline Grass (Puccinellia nuttalliana) & United States & 1 & 6 & Yes & 3 \\
\hline Grass (Puccinellia nuttalliana) & United States & 1 & $2-12$ & Yes & 4 \\
\hline Iliamna (Malvaceae) & North America & 8 & 4 & Yes & 5 \\
\hline Kelp (Alaria) & Global & 1 & $4-5$ & Yes & 6 \\
\hline Orchids (Corallorhiza maculata) & Central and North America & 1 & 3 & Yes & 7 \\
\hline Pacific Coast irises & Pacific Coast USA & 1 & 5 & Yes & 8 \\
\hline \multicolumn{6}{|c|}{ Fungus } \\
\hline $\begin{array}{l}\text { Ascomycete fungi (Aspergillus } \\
\text { flavus) }\end{array}$ & Australia & 2 & 2 & No & 9 \\
\hline $\begin{array}{l}\text { Asexual fungi (Fusarium / } \\
\text { Giberella fujikuroi complex) }\end{array}$ & Global & 9 & 45 & Yes & 10 \\
\hline $\begin{array}{l}\text { Asexual fungus (Fusarium } \\
\text { oxysporum group) }\end{array}$ & Global & 1 & $5-6$ & Yes & 11 \\
\hline Fungus & Global & $22-45$ & 45 & Unknown & 12 \\
\hline Fungi (Aspergillus fumigatus) & Global & 1 & 2 & Yes & 13 \\
\hline Fungi (Fusarium graminearum) & Global & 1 & 7 & Yes & 14 \\
\hline Fungi (Fusarium oxysporum) & Global & 1 & 5 & Yes & 15 \\
\hline Fungi (Histoplasma) & Western Hemisphere & 1 & 6 & Yes & 16 \\
\hline Fungi (Histoplasma capsulatum) & Western Hemisphere & 1 & 6 & No & 17 \\
\hline Mushrooms & Asia & 1 & 4 & Yes & 18 \\
\hline Pathogenetic fungi & Western USA & 1 & 2 & Yes & 19 \\
\hline Pathogenic fungus & Global & 3 & 8 & Unknown & 20 \\
\hline \multicolumn{6}{|c|}{ Lichen } \\
\hline Lichen (Niebla) & Western USA & 18 & 71 & Unknown & 21 \\
\hline Lichenized alga & Global & 1 & $6-7$ & Yes & 22 \\
\hline Lichenized fungi & Global & 2 & 6 & Unknown & 23 \\
\hline Lichenized fungi & Global & 2 & 6 & No & 24 \\
\hline $\begin{array}{l}\text { Lichenized fungus (Ramilina } \\
\text { americana) }\end{array}$ & Appalachian mountains, USA & 1 & 2 & Yes & 25 \\
\hline \multicolumn{6}{|c|}{ Birds } \\
\hline Australasian teals & Australasia & 5 & 5 & Equal & 26 \\
\hline Birds & New Zealand & 235 & 245 & Unknown & 27 \\
\hline Birds & Netherlands & 39 & 52 & Unknown & 28 \\
\hline Birds of Paradise & New Guinea & $40-42$ & $80-120$ & Unknown & 29 \\
\hline Birds of Paradise & New Guinea & $40-42$ & 90 & No & 30 \\
\hline Cape Verde birds & Cape Verde & 26 & 40 & Yes & 31 \\
\hline Endemic birds & Mexico & 101 & 249 & Unknown & 32 \\
\hline Forest robins & Africa & 3 & 4 & Yes & 33 \\
\hline Fox sparrow & North America & $1-4$ & 4 & Yes & 34 \\
\hline Huet-huets and turcas & Chile & 3 & 3 & Equal & 35 \\
\hline Kiwi & New Zealand & $1-2$ & 2 & No & 36 \\
\hline Northern oriole & North America & 1 & 2 & Yes & 37 \\
\hline Parakeets & Neotropics & 2 & $8-11$ & Yes & 38 \\
\hline Ravens & Global & 2 & 3 & No & 39 \\
\hline Scaled woodcreepers & Brazil & 2 & 3 & Yes & 40 \\
\hline Sharp-beaked ground finch & Galapagos & 1 & 2 & Yes & 41 \\
\hline Sharp-tailed sparrow & North America & 1 & 2 & Yes & 42 \\
\hline Spotted owl & West Coast USA & 1 & 3 & Yes & 43 \\
\hline Swamp hens & New Zealand & 2 & 8 & No & 44 \\
\hline
\end{tabular}


TABLE 1

Comparing nonphylogenetic and phylogenetic species (continued)

Australian bats
Bottlenose dolphin
Brown lemur
Deer mouse
Marten
Right whales (Eubalena)
Spiny rats
Tiger
Titi monkies (Callicebus)
Wooly mouse oppossums
Bee family (Halictidae)
Brown planthoppers
Cantharid beetles
Cotton stainer bugs (Dysdercus)
Copepod
Copepod
Copepod
Pomace flies (Drosophila
willistoni)
Flightless chafer beetles
Harpacticoid copepod
Shield shrimps
Snapping shrimps
Tasmanian mountain shrimps
Gopher snake
Green salamander
Pacific skinks
Pitvipers
Short-necked turtles
Spiny lizard
Spitting cobras

European freshwater fishes

Troglobitic catfish

Deep-sea snails

Hawaiian tree snails

Intertidal snails

Linckia starfish

Sea urchins

Six-rayed starfish

Hard-rayed coral (Montastraea annularis)

Reef-building corals

Oligochaete worm (Tubifex tubifex)

Polychaete worm

Frogs

Malaria parasites

Vertebrates
Mammals

Australia

Global

Madagascar

Mexico

North America

Global

Amazonia

Asia

Neotropics

Amazonia

Arthropods

Canada

Asia and Australia

North America

New World

Eastern North Pacific

Eastern North Pacific

Eastern North Pacific

Global

No

Yes

Yes

Yes

Yes

No

Yes

Yes

Yes

Yes

Yes

Equal

Equal

Yes

Yes

Yes

Yes

Yes

Reverse

Yes

No

Yes

Yes (4) / No (3)

Yes

Yes

No

Equal

Yes (7) / No (3) $\quad 72$

Yes $\quad 73$

Yes 74

Fish

Europe (exclusive of former USSR) $\quad 213 \quad 358$

Brazil

1

Unknown

Yes

Reverse

Reverse

Reverse

Hawaii

Ireland

Echinoderms

Indian and Pacific ocean

Global

Eastern North Pacific

$$
\begin{aligned}
& \text { Corals } \\
& \text { Caribbean } \\
& \text { Global Annelids }
\end{aligned}
$$

North America and Europe

Miscellaneous

Sub-Saharan Africa

Caribbean Islands

Global
Yes

Yes (4) / No (3)

Reverse

Yes

Reverse

3

1

Yes

Yes

86

1

3

Unknown

Equal

Unknown

\begin{tabular}{cccc}
$1-3$ & 10 & Unknown & 87 \\
2 & 2 & Equal & 88 \\
252 & $252-392$ & Unknown & 89 \\
\hline
\end{tabular}

45

47

48

49

50

51

52

53

54

55

56

57

58

59

60

61

62

63

64

65

66

67

68

69

70 1

$$
74
$$


References: 1) Levin 1998. 2) Snow 1996. 3) Davis and Manos 1991. 4) Davis and Goldman 1993.5) Boda Slotta 2000.6) Kraan and Guiry 2000. 7) Freudenstein and Doyle 1994. 8) Young 1998. 9) Geiser et al. 1998. 10) Taylor et al. 1999. 11) Taylor et al. 1999. 12) Taylor et al. 2000. 13) Rinyu et al. 1995. 14) O’Donnell et al. 2000. 15) O’Donnell 1998. 16) Kasuga et al. 1999. 17) Kasuga et al. 1999. 18) Hibbett and Donoghue 1996. 19) Koufopanou et al. 1997. 20) Koufopanou et al. 2001. 21) Spjut 1996. 22) Kroken and Taylor 2000. 23) Grube and Kroken 2000. 24) Kroken and Taylor 2001. 25) LaGreca 1999. 26) Daugherty et al. 1999. 27) Holdaway et al. 2001. 28) Sangster et al. 1997. 29) Collar 1997. 30) Cracraft 1992. 31) Hazevoet 1995; Hazevoet 1996. 32) Peterson and Navarro-Sigüenza 1999. 33) Beresford and Cracraft 1999. 34) Zink 1994. 35) Chesser 1999. 36) Baker et al. 1995. 37) Freeman and Zink 1995. 38) Joseph 2000. 39) Omland et al. 2000. 40) da Silva and Sraube 1996. 41) Grant et al. 2000. 42) Greenlaw 1993. 43) Barrowclough et al. 1999. 44) Sangster 1998. 45) Cooper et al. 1998. 46) Wang et al. 1999. 47) Wyner et al. 1999. 48) Harris et al. 2000. 49) Carr and Hicks 1997. 50) Rosenbaum et al. 2000. 51) da Silva and Patton 1998. 52) Cracraft et al. 1998. 53) Van Roosmalen 2002. 54) da Silva and Patton 1998. 55) Packer and Taylor 1997. 56) Jones et al. 1996; Claridge et al. 1997. 57) Howard and Shields 1990. 58) Zrzavy and Nedved 1997. 59) Ganz and Burton 1995. 60) Burton and Lee 1994. 61) Burton and Lee 1994. 62) Gleason et al. 1998. 63) Emerson and Wallis 1994. 64) Schizas et al. 1999. 65) King and Hanner 1998. 66) Knowlton 1993. 67) Jarman and Elliot 2000. 68) Rodríguez-Robles and de Jesús-Escobar 2000. 69) K A Crandall, personal communication. 70) Bruna et al. 1996. 71) Puorto et al. 2001. 72) Georges and Adams 1996. 73) J C Marshall, personal communication. 74) Wüster and Thorpe 1994. 75) Kottelat 1997. 76) Hoenen 1998. 77) Shank et al. 1999. 78) Thacker and Hadfield 2000. 79) Small and Gosling 2000. 80) Williams 2000. 81) Lessios et al. 2001. 82) Flowers and Foltz 2001. 83) Medina et al. 1999. 84) Knowlton and Weigt 1997. 85) Sturmbauer et al. 1999. 86) Bastrop et al 1998. 87) Wieczorek et al. 2001. 88) Perkins 2000. 89) Avise and Walker 1999.

$p<.0001, z$ value of 5.82. It is true these populations may, by their very nature, be a biased sample. Taxonomic reassessment will often focus on groups where there is dissatisfaction with current understanding. The wide variety of taxa studied, however, the consistent increase in species numbers, and its agreement with previous estimates (e.g., Zink and McKitrick 1995) imply that the trend is approximate but correct. This trend of increasing species counts appears to contradict a previous study based on fossil data (Alroy 2002) that postulated synonymous or otherwise invalid taxa were inflating the global species count by up to $30 \%$. However, we feel that optimistic estimation of fossil coverage and ignoring the vastly different techniques used to delineate species in living and fossil taxa render such an extrapolation meaningless.

It is difficult to detect any trend across groups, and given the small sample size and how it was obtained, any putative trends should be treated with suspicion. With this in mind, the greatest increase in species numbers was seen in fungus, a $300 \%$ increase. This may in part reflect the confused taxonomy in the field (Hawksworth 1993). Similar comments could be made about lichens (259\% increase) and plants ( $146 \%$ increase). Among animals, reptiles showed the greatest increase (137\%). It is startling that taxonomically well-studied groups like mammals, arthropods, and birds showed large and roughly similar increases $(87 \%, 77 \%$, and $88 \%$, respectively). The relatively small increase in echinoderm species $(8 \%)$ can perhaps be explained by this group being conspicuous, species poor, and thoroughly investigated. The marked decrease in mollusc species $(50 \%)$ is perplexing. Perhaps it is due to the past activities of amateur mollusc taxonomists, who may have been overenthusiastic in identifying new species.

Another important consideration for conservation is how changes in the classification and number of species under the PSC map onto the previous species distributions. With conflicting species identifications, the newly defined species may either nest within the previously recognized species ("nested redefinition"), cross the boundaries of two or more of the former species ("non-nested redefinition"), or represent the fusion of several species ("reverse nesting") (Figure 1). Only fifteen of the studies examined $(17.0 \%)$ showed a definite non-nesting of the PSC-defined species. However, this fact should be tempered with the knowledge that another six showed reverse nesting (i.e., merging of two or more non-PSC-based species into a single entity) and boundaries changes were not available for eleven studies. Again, it is difficult to draw trends across groups, but non-nested redefinitions may be more prevalent in the birds, possibly because of increased taxonomic attention.

\section{Consequences}

From the above analysis it can be seen that reclassification via use of the PSC leads to an 
apparent increase in the number of species and a more modest remapping of species across previous taxonomic boundaries. As far as biodiversity studies are concerned, the consequences of this fall into a number of categories: the change in the number of endangered species, the economic and political fallout, and conservation practice.

Reclassification under the PSC will lead to an apparent rise in the number of endangered species. This is due not only to the detection of "new" species but also to an increase in the proportion that are endangered due to a reduction in the distributional area of the inferred species range. Because the new species tend to arise through the splitting of previous entities, the abundance of and area occupied by each can at best be a subset of the previous values. Both measures can therefore be expected to decline on average. Formal classifications of endangered species like the IUCN Red List (Baillie and Groombridge 1996) use both number of individuals and geographic range as diagnostics. We can therefore expect at least a proportionate or greater increase in the number of threatened species.

It is possible to estimate the impact of these decreases on formal threat classifications. For example, the IUCN category "Vulnerable" identifies species that are at a high risk of extinction based on (among other criteria) the species having fewer than 1000 mature individuals. The threat category above, "Endangered," defines those species at a very high risk of extinction by having fewer than 250 mature individuals. The $48.7 \%$ increase in species number that we observed infers an average decrease in mature individuals per species of $32.8 \%$. If we assume the number of mature individuals in "Vulnerable" species are distributed evenly throughout the band of possible values (250 to 1000 ), a $32.8 \%$ drop will cause $10.9 \%$ of these species to have less than 250 mature individuals and so be reclassified as "Endangered." This is a conservative estimate as it assumes that the new species are of equal size, whereas unequal splitting will produce more small groups in the "Vulnerable" category.

The impact on species range is more difficult to formalize. For example, a $50 \%$ drop in the number of adult individuals does not necessarily imply a $50 \%$ drop in range. Nonetheless, as use of the PSC splits and therefore shrinks species, the new entities will tend to have reduced ranges. By virtue of this, the proportion of species formally classified as endangered will increase.

Any increase in the number of endangered species requires a corresponding increase in resources and money devoted toward conserving those species. For example, it has been estimated that the complete recovery of any of the species listed by the U.S. Endangered Species Act will require about $\$ 2.76$ million (USFWS 1994). Thus, recovering all species listed currently would cost around $\$ 4.6$ billion. With widespread adoption of the PSC, this already formidable amount could increase to $\$ 7.6$ billion, or the entire annual budget for the administering agency (U.S. Fisheries and Wildlife Services) for the next 120 years. The per-species cost is admittedly high-being based on the costs to save what are sometimes subspecies or already critical populations-but given that species size and range will fall on average, and that cost of rescue rises with the degree of threat, total costs might actually reach far beyond this point. Resurveying taxa of importance for consistent species recognition would involve less money, but still requires amounts that are nontrivial considering the disagreement over species concepts. An evaluation of the threat status of 120,000 potentially threatened tropical taxa has been proposed, conservatively valued at $\$ 100$ per species, summing to a relatively modest $\$ 12.1$ million (Pitman and Jorgenson 2002). A higher figure of $\$ 135$ million can be calculated by assuming Platnick's figures for a dedicated taxonomic team (Platnick 1999). If this resurvey were to reveal only $10 \%$ of these taxa as endangered, the rescue bill could amount to $\$ 33.1$ trillion. Even just formally listing these taxa as endangered would, by USFWS figures, cost $\$ 816$ million. These figures are arguably acceptable to industrial nations, but frankly impossible for many impoverished and biodiverse countries. It has been said that the economic cost of current conservation strategies are already unacceptable (Mann and Plummer 1995). The impact of the PSC serves only to reinforce this 
point, and may require a rethinking of policies that seek to preserve every species (Moulton and Sanderson 1999).

If more resources are needed, then there is also a need for more education and mobilization of opinion. Unfortunately, disagreement between species concepts may present problems. Public concern has a great influence over the allocation of conservation resources, it being easier to find money for the preservation of charismatic, easily recognized organisms than for more obscure and less appealing ones, independent of their evolutionary or ecological significance or conservation status (Ando 1999; Gittleman et al. 2001). Changing species identities and a flood of threatened species may create confusion and apathy in the public's mind. Furthermore, consistent application of the PSC may make this task more difficult by identifying morphologically disparate entities as members of the same species and superficially similar entities as members of different species (Wayne and Gittleman 1995; Bruna et al. 1996). This is not to say that only easily "marketable" species should be saved, but conservation biologists should prepare for the difficulties caused by a change in species identity and numbers. Taxonomy may be seen as the enemy of conservation due to these unpalatable implications (for example, see Collar 1997). Complex ideas of species identity under the PSC may also thwart the use of parataxonomists, who have proven so useful in covering remote biodiverse areas. Conversely, application of the BSC in the field can also be difficult. If the application of the PSC reveals more species and increases the threat status of those groups, more taxonomic and conservation attention may be drawn to groups neglected under previous regimes.

Changing species boundaries may also cast doubt on the efficacy of current conservation schemes, leading to arguments about whether conservation efforts are being correctly allocated and prioritized. This is exacerbated by the tendency of conservation schemes to focus on reserves and protected regions. The endemic birds of Mexico provide an excellent illustration of this point (Peterson and Navarro-Sigüenza 1999).
Under the BSC there are 101 species, concentrated in the mountains of southern and western Mexico. Under the PSC, however, the number of species increases to 249 , with a general concentration in the west of Mexico. Any effort directed at widespread preservation of Mexico's avian biodiversity based on either classification would, from the point of view of the other, be preserving many of the "wrong" regions (Figure 2); for further examples, see Daugherty et al. 1990, O'Brien and Mayr 1991, Soltis and Gitzendanner 1999, and Bates and Demos 2001. Shifts in species concept effectively change the importance of different taxonomic groups for identifying regions of biodiversity. The question changes from one of where the biodiversity is to one of which species concept is more appropriate.

The redefinition of species, where new entities cross the boundaries of the old, also casts doubt on the efficacy of conservation schemes. Even with a consistent species concept this may happen, but changing concepts may exacerbate this problem. Where redefinition of species is reverse nested, we should expect few problems. Schemes directed at saving the old species should be suitable, and perhaps even excessive, for saving the new species. Nested and non-nested redefinitions pose a greater problem, as anything less than total preservation of the old species may leave some of the new species uncovered. Given the sample size of this survey and the relatively small number of clades that demonstrate non-nested rearrangements, it is not clear if this problem will be widespread. Nonetheless, the examples unearthed should serve as grounds for caution. If a mix of concepts is used to define species in a survey of species abundance, disagreement over critical areas of biodiversity could result.

\section{ReMEdies}

What, then, are we to do? Rejecting the PSC solely because of (apparently) unpleasant biodiversity implications smacks of expedience. Reverting to the BSC ignores its operational problems. Indeed, it is perhaps not a question of which species concept is best. There may be no one solution to the species concept issue, with particular concepts being more apt in different circumstances (Hey 


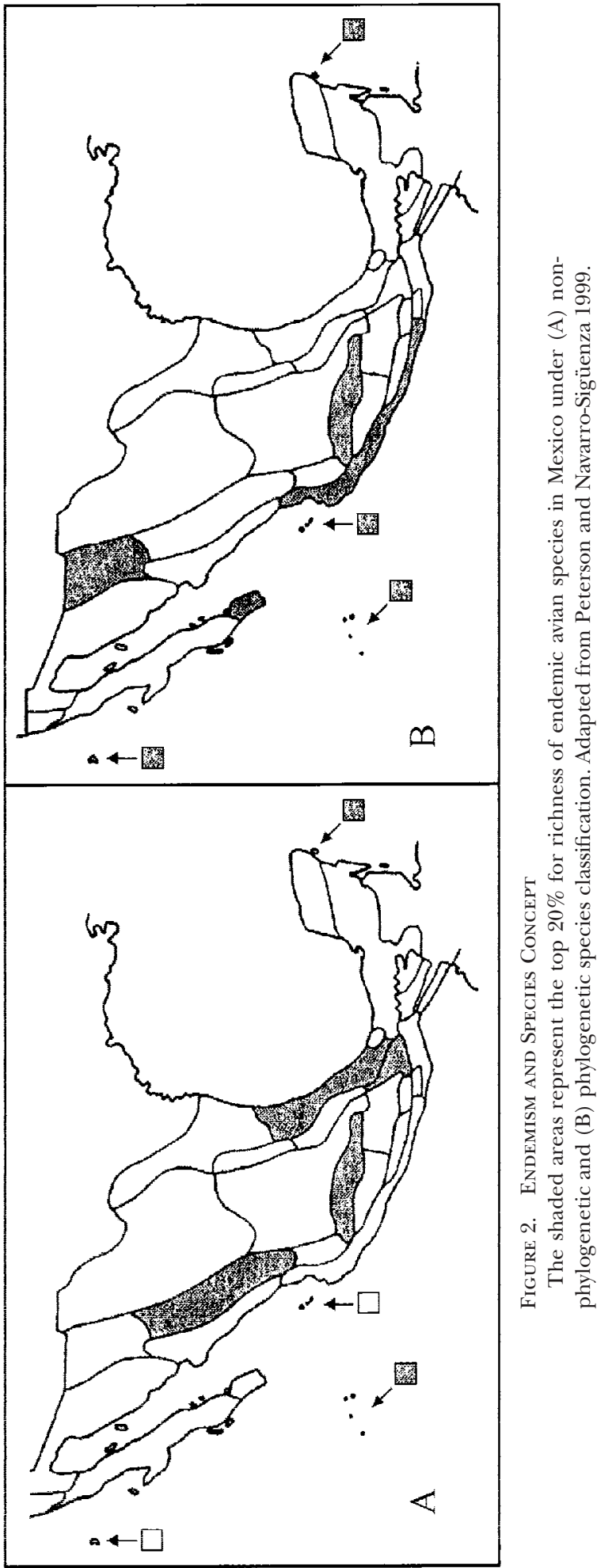


2001; Mace et al. 2003). A plurality of species definitions is likely to remain part of biology and the conservation landscape. Conservation biologists will remain trading in a variety of "currencies," and concern for what is lost will be conflated by confusion over how much is lost (Rojas 1992).

A few broad remedies can be suggested. Where species lists are being used in conservation, it is necessary to be clear about how the species involved were defined. In this way, one can move toward consistency and replicability of any conclusions, or at least clarity about how the conclusions can be flawed. The BSC should be used only where it can be robustly diagnosed and the grounds for this inference made clear. Species inferred from morphology should always be treated as tentative. Where the PSC is used, sufficient individuals and characters should be sampled to ensure an adequate and even resolution of the species status across clades (Walsh 2000). However, even consistent use of a single concept does not guarantee consistent species boundaries. As stated above, ring and hybrid populations present an intractable problem for the BSC. A strict interpretation of the concept in these cases is uninformative, while more relaxed interpretations are subjective and possibly inconsistent. The PSC has been implemented under a wide variety of methodologies-e.g., population aggregation analysis (Davis and Nixon 1992), cladistic haplotype aggregation (Brower 1999), genealogical concordance (Baum and Shaw 1995), and gene trees with geographical concordance (Wiens and Penkrot 2002) —and it has been shown that these need not agree (Wiens and Penkrot 2002). It may be possible that different species concepts and methods can be used to reinforce each other, so as to reach consistent if conservative conclusions on species boundaries (e.g., Jarman and Elliott 2000). Any move toward greater consistency in classifying species will also require an increase in the resources devoted toward unifying taxonomy and making it more accessible (Godfray 2002).

Much of the problem may rest in the implicit assumption that species are distinct entities. In reality, species are probably not groups with rigid borders but "fuzzy sets"
(Hey 2001; Mallet 2001b; Hendry et al. 2002), their boundaries blurred by horizontal gene transfer, hybridization, and recent isolation. Furthermore, species can arise by a variety of mechanisms, and different concepts consider different characteristics of a population. It is thus little wonder that each concept diagnoses a different sort of "species." Obviously, a single morpho-species can contain multiple species (sensu BSC or PSC) where morphology is cryptic or a limited number of characters are studied (Kasuga et al. 1999; Taylor et al. 2000). More subtly, the diagnostic form of the BSC emphasizes potential gene flow, conflating it with the actual lack of gene flow that may be both the cause and result of a species boundary (Templeton 1989). Species recognized as separate by the PSC may be lumped into a single species by the BSC, even if they are genetically and geographically separated (Vilgalys and Sun 1994). Given that interbreeding is still possible, at some point in the future the separate species (sensu PSC) may reticulate back into a single entity. Conversely, as genetic isolation precedes the loss of shared polymorphisms, shortly after the separation of two biological species the PSC may only recognize a single species (Doyle 1997). Thus we do not even have the certainty that PSC-based species will fall within biological species and biological species within morpho-species. The problem is not in any particular species concept, but in the nature of species.

Even if species could somehow be unambiguously defined, there are problems. If biological species are used, it is unclear how hybrid populations should be treated (see below). Also, while it has been argued that under the PSC species come closer to being ESUs (evolutionary significant units) (Ryder 1986) than any other defined entity (Cracraft 1997), this advantage is lost in the apparent lack of applicability of ESUs in the real world (Crandall et al. 2000; Hendry et al. 2002). Finally, while current conservation measures are often biased toward charismatic taxa (Metrick and Weitzman 1998; Gittleman et al. 2001), diagnosing biodiversity by counting species errs in the other direction by insisting that all species are equally important (May 1990). A large number of species does cor- 
respond to general ecosystem stability (Naeem 1998), but the identification of a species as such does not say anything about its evolutionary distinctiveness or ecological importance. Species-centered conservation necessarily neglects the conservation-worthy diversity found within and between species, i.e., subspecies and hybrids (Balharry et al. 1994; Rieseberg and Gerber 1995; GarcíaMoreno et al. 1996). Thus, species counts, however derived, are only the first step of diagnosing biodiversity.

Would it therefore be best to avoid the use of species? If so, the conservation worth of a population must be appraised in another currency, such as economic value, aesthetic appeal, or unique genetic and evolutionary information. Examples of this last type include phylogenetic diversity (Faith 1994), genetic diversity (Crozier 1997), phenotypic diversity (Owens and Bennett 2000), or taxonomic units based solely on evolutionary time (Avise and Johns 1999). In this way, biodiversity value can be measured in information: diversity measured as millions of years, allelic distance, or character richness. Conservation schemes can be designed so as to maximize the amount of information preserved. Highly diverse but putative species could be given the benefit of the doubt. In some cases, it might be proper for a divergent subspecific entity to be valued over a more conserved species. Such measures do not entirely obviate the need for identifying species, however. Comparing the biodiversity value of, for example, species of cetaceans and woodchucks is at least plausible if not always meaningful. Doing the same via information measures of cetacean and woodchuck populations introduces more possibilities for ambiguity and argument. Information measures can be sensitive to sampling effects, monotonically increasing with every organism examined. The use of measures other than species counts also forces us to ask what it is that we are trying to preserve. Phylogenetic and genetic diversity may be easy to measure, but it is far from clear that they are precisely what needs saving. Also, any attempt to abolish the use of species sacrifices the usefulness of discrete, identifiable units of conservation important for raising public sympathies.
At the opposite end of the scale, the species problem could be avoided by working to conserve higher taxa, supraspecific groups. These at least can usually be identified without controversy, and the broad outline of biodiversity preserved (Williams and Gaston 1994). This preservation is bought, however, at the possible expense of the fine detail of diversity and ecosystem stability. Furthermore, even if higher taxa are the focus of conservation, management plans must still consider species boundaries and whether groups of individuals are genetically and ecologically distinct (Crandall et al. 2000). Given that many species identities may remain ambiguous, or even undiscovered, for a long time, perhaps planning should concentrate on preserving areas where new species are likely to be uncovered. For example, the preservation of "Endemic Bird Areas" have been proposed (ICBP 1992; Jepson and Whittaker 2002), based on the idea that areas known to be endemic for some species are likely to be endemic for unknown species as well (Balmford and Long 1995). This is a more palatable solution than waiting for a perfect understanding of species boundaries that may never arrive.

While there is much to be said for deemphasizing the importance of species in conservation decisions, they are far from dispensable. Indeed, the species problem is emblematic of conservation and the gulfs between science policy and practice. We would do the right thing, if only we knew what the right thing was. The best response to the terrible ambiguity of species may be for scientists not to work to reduce it nor to fear making conservation mistakes, but to learn how to work with it. "One size fits all" solutions based on identifying the "right" species may have to be abandoned for a flexible spectrum of methodologies that either employ a range of species concepts or dispense with species altogether. Most difficult of all may be the task of translating ambiguous species boundaries into workable guidelines for legislators, decision makers, and the layperson. Without action, we risk losing much time, much money, and much biodiversity.

\section{ACKNOWLEDGMENTS}

This work resulted from a workshop organized and supported by JLG, conducted at the National Center 
for Ecological Analysis and Synthesis, a center funded by the NSF (grant DEB-94-21535), the University of California at Santa Barbara, and the State of California. P-MA was supported by the Natural Environment Research Council UK (grant GR3/11526) and Biotechnology and Biological Sciences Research Council
(UK). OB-E was supported in part by an NSERC (Canada) postdoctoral fellowship. We thank Jonathan Baillie, Alexandra Baillie, Ross Crozier, Jim Mallet, Joan McGalliard, Neil Snow, and two anonymous reviewers for valuable comments and advice.

\section{REFERENCES}

Alroy J. 2002. How many named species are valid? Proceedings of the National Academy of Sciences USA 99:3706-3711.

Amadon D, Short L L. 1992. Taxonomy of lower categories. Bulletin of the British Ornithological Club112A: 11-38.

Ameziane N, Roux M. 1997. Biodiversity and historical biogeography of stalked crinoids (Echinodermata) in the deep sea. Biodiversity and Conservation 6: 1557-1570.

Ando A W. 1999. Waiting to be protected under the endangered species act: the political economy of regulatory delay. Journal of Law $\mathcal{E}$ Economics 42:2960.

Avise J C, Johns G C. 1999. Proposal for a standardized temporal scheme of biological classification for extant species. Proceedings of the National Academy of Sciences USA 96:7358-7363.

Avise J C, Walker D. 1999. Species realities and numbers in sexual vertebrates: perspectives from an asexually transmitted genome. Proceedings of the National Academy of Science USA 96:992-995.

Baillie J E M, Groombridge B. 1996. IUCN Red List of Threatened Animals. Gland (Switzerland): IUCN.

Baker A J, Daugherty C H, Colbourne R, McLennan J L. 1995. Flightless brown kiwis of New Zealand possess extremely subdivided population structure and cryptic species like small mammals. Proceedings of the National Academy of Sciences USA 92:82548258.

Balharry E, Staines B W, Marquiss M, Kruuk H. 1994. Hybridisation in British Mammals. Peterboroug (UK): Joint Nature Conservation Committee.

Balmford A, Long A. 1995. Across-country analyses of biodiversity congruence and current conservation effort in the tropics. Conservation Biology 9:15391547.

Barrowclough G F, Gutiérrez R J, Groth J G. 1999. Phylogeography of spotted owl (Strix occidentalis) populations based on mitochondrial DNA sequences: gene flow, genetic structure, and a novel biogeographical pattern. Evolution 53:919931.

Bastrop R, Jürss K, Sturmbauer C. 1998. Cryptic species in a marine polychaete and their independent introduction from North America to Europe. Molecular Biology and Evolution 15:97-103.

Bates J M, Demos T C. 2001. Do we need to devalue
Amazonia and other large tropical forests? Diversity and Distributions 7:249-255.

Baum D A, Shaw K L. 1995. Genealogical perspectives on the species problem. Pages 289-303 in Experimental and Molecular Approaches to Plant Biosystematics, edited P C Hoch and A G Stephenson. St. Louis (MO): Missouri Botanical Garden.

Beresford P, Cracraft J. 1999. Speciation in African forest robins (Stiphrornis): species limits, phylogenetic relationships, and molecular biogeography. American Museum Novitates 3270:1-22.

Bodo Slotta T A. 2000. Phylogenetic analysis of Iliamna (Malvaceae) using the internal transcribed spacer region [PhD dissertion]. Blacksburg (VA): Virginia Polytechnic Institute.

Brower A V Z. 1999. Delimitation of phylogenetic species with DNA sequences: a critique of Davis and Nixon's population aggregation analysis. Systematic Biology 48:199-213.

Bruna E M, Fisher R N, Case T J. 1996. Morphological and genetic evolution appear decoupled in Pacific skinks (Squamata: Scincidae: Emoia). Proceedings of the Royal Society of London B 263:681-688.

Burton R S, Lee B-N. 1994. Nuclear and mitochondrial gene genealogies and allozyme polymorphism across a major phylogeographic break in the copepod Tigriopus californicus. Proceedings of the National Academy of Sciences USA 91:5197-5201.

Carr S M, Hicks S A. 1997. Are there two species of marten in North America?: genetic and evolutionary relationships within Martes. Pages 15-28 in Martes: Taxonomy, Ecology, Techniques, and Management, edited G Proulx, H N Bryant, and P M Woodard. Alberta (Canada): Provincial Museum of Alberta, Edmonton.

Chesser R T. 1999. Molecular systematics of the rhinocryptid genus Pteroptochos. Condor 101:439-446.

Claridge M F, Dawah H A, Wilson M R. 1997. Practical approaches to species concepts for living organisms. Pages 1-15 in Species: The Units of Biodiversity, edited by M F Claridge, H A Dawah, and M R Wilson. London: Chapman and Hall.

Collar NJ. 1997. Taxonomy and conservation: chicken and egg. Bulletin of the British Ornithological Council 117:122-136.

Collar N J, Crosby M J, Stattersfield AJ. 1994. Birds to Watch 2: The World List of Threatened Birds. Cambridge: BirdLife International. 
Cooper S J B, Reardon T B, Skilins J. 1998. Molecular systematics of Australian rhinolophid bats (Chiroptera: Rhinolophidae). Australian Journal of Zoology 46:203-220.

Corbet G B. 1997. The species in mammals. Pages 341-356 in Species: The Units of Biodiversity, edited by M F Claridge, H A Dawah, and M R Wilson. London: Chapman and Hall.

Cracraft J. 1983. Species concepts and speciation analysis. Current Ornithology 1:159-187.

Cracraft J. 1992. The species of the birds-of-paradise (Paradisaeidae): applying the phylogenetic species concept to a complex pattern of diversification. Cladistics 8:1-43.

Cracraft J. 1997. Species concepts in systematics and conservation biology-an ornithological viewpoint. Pages 325-339 in Species: The Units of Biodiversity, edited by $\mathrm{M}$ F Claridge, $\mathrm{H}$ A Dawah, and $\mathrm{M}$ R Wilson. London: Chapman and Hall.

Cracraft J, Feinstein J, Vaughn J, Helm-Bychowski K. 1998. Sorting out tigers (Panthera tigris): mitochondrial sequences, nuclear inserts, systematics, and conservation genetics. Animal Conservation 1:139150.

Crandall K A, Bininda-Emonds O R P, Mace G M, Wayne R K. 2000. Considering evolutionary processes in conservation biology. Trends in Ecology $\mathcal{E}$ Evolution 15:290-295.

Crozier R H. 1997. Preserving the information content of species: genetic diversity, phylogeny and conservation worth. Annual Reviews in Ecology and Systematics 28:243-268.

da Silva J M C, Sraube F C. 1996. Systematics and phylogeography of scaled woodcreepers (Aves: Dendrocolaptidae). Studies on Neotropical Fauna and the Environment 31:3-10

da Silva M N F, Patton J L. 1998. Molecular phylogeography and the evolution and conservation of Amazonian mammals. Molecular Ecology 7:475-486.

Daugherty C H, Cree A, Hay J M, Thompson M B. 1990. Neglected taxonomy and continuing extinction of the tuatara (Sphenodon). Nature 347:177179 .

Daugherty C H, Murray W, Hay J M. 1999. Genetic differentiation, taxonomy and conservation of Australasian teals Anas spp. Bird Conservation International 9:29-42.

Davis J I, Goldman D H. 1993. Isozyme variation and species delimitation among diploid populations of the Puccinellia nuttalliana complex (Poaceae): character fixation and the discovery of phylogenetic species. Taxon 42:585-599.

Davis J I, Manos P S. 1991. Isozyme variation and species delimitation in the Puccinellia nuttalliana complex (Poaceae): an application of the phylogenetic species concept. Systematic Botany 16:431-445.

Davis J I, Nixon K C. 1992. Populations, genetic vari- ation, and the delimitation of phylogenetic species. Systematic Biology 41:421-435.

de Quieroz K, Donoghue M J. 1988. Phylogenetic systematics and the species problem. Cladistics 4:317338.

de Quieroz K, Donoghue M J. 1990. Phylogenetic systematics and species revisited. Cladistics 6:83-90.

Donoghue M J. 1985. A critique of the biological species concept and recommendations for a phylogenetic alternative. Bryologist 88:172-181.

Doyle J J. 1997. Trees within trees: genes and species, molecules and morphology. Systematic Biology 46: 537-553.

Emerson B C, Wallis G P. 1994. Species status and population genetic structure of the flightless chafer beetles, Prodontria modesta and P. bicolorata (Coleoptera: Scarabaeidae) from South Island, New Zealand. Molecular Ecology 3:339-345.

Ereshefsky M. 1999. Species and Linnaean hierarchy. Pages 285-305 in Species: New Interdisciplinary Essays, edited by R A Wilson. London: MIT Press.

Erwin D H, Anstey R L, editors. 1995. New Approaches to Speciation in the Fossil Record. New York: Columbia University Press.

Faith D P. 1994. Phylogenetic diversity: a general framework for the prediction of feature diversity. Pages 251-268 in Systematics and Conservation Evaluation, edited by P L Forey, C J Humphries, and R I Vane-Wright. Oxford: Clarendon Press.

Flowers J M, Foltz D W. 2001. Reconciling molecular systematics and traditional taxonomy in a speciesrich clade of sea stars (Leptasterias subgenus Hexasterias). Marine Biology 139:475-483.

Freeman S, Zink R M. 1995. A phylogenetic study of the blackbirds based on variation of mitochondrial DNA restriction sites. Systematic Biology 44:409-420.

Freudenstein J V, Doyle J J. 1994. Plastid DNA, morphological variation, and the phylogenetic species concept: the Corallorhiza maculata (Orchidaceae) complex. Systematic Botany 19:273-290.

Ganz H H, Burton R S. 1995. Genetic differentiation and reproductive incompatibility among Baja California populations of the copepod Tigriopus californicus. Marine Biology 123:821-827.

García-Moreno J, Matocq M D, Roy M S, Geffen E, Wayne R K. 1996. Relationships and genetic purity of the endangered Mexican wolf based on analysis of microsatellite loci. Conservation Biology 10:376389

Geiser D M, Pitt J I, Taylor J W. 1998. Cryptic speciation and recombination in the aflatoxin-producing fungus Aspergillus flavus. Proceedings of the National Academy of Sciences USA 95:388-393.

Georges A, Adams M. 1996. Electrophoretic delineation of species boundaries within the short-necked freshwater turtles of Australia (Testudines: Chelidae). Zoological Journal of the Linnean Society 118: 241-260. 
Ghiselin M T. 1987. Species concepts, individuality, and objectivity. Biology E Philosophy 2:127-143.

Gittleman J L, Funk S, Macdonald D W, Wayne R W. 2001. Why 'carnvivore conservation'? Pages 1-7 in Carnivore Conservation, edited by J L Gittleman et al. Cambridge: Cambridge University Press.

Gleason J M, Griffith E C, Powell J R. 1998. A molecular phylogeny of the Drosophila willistoni group: conflicts between species concepts? Evolution 52: 1093-1103.

Godfray H C J. 2002. Challenges for taxonomy. Nature 417:17-19.

Grant P R, Grant B R, Petren K. 2000. The allopatric phase of speciation: the sharp-beaked ground finch (Geospiza difficilis) on the Galápagos islands. Biological Journal of the Linnean Society 69:287-317.

Greenlaw J S. 1993. Behavioral and morphological diversification in sharp-tailed sparrows (Ammodramus caudacutus) of the Atlantic coast. Auk 110:286303.

Grube M, Kroken S. 2000. Molecular approaches and the concept of species and species complexes in lichenized fungi. Mycological Research 104:12841294.

Harris D, Rogers D S, Sullivan J. 2000. Phylogeography of Peromyscus furvus (Rodentia; Muridae) based on cytochrome $b$ sequence data. Molecular Ecology 9:2129-2135.

Harrison R G. 1998. Linking evolutionary pattern and process. Pages 19-31 in Endless Forms, edited by D J Howard and S H Berlocher. Oxford: Oxford University Press.

Hawksworth D L. 1993. The tropical fungal biota: census, pertinance, prophylaxis, and prognosis. Pages 265-293 in Aspects of Tropical Mycology, edited by S Isaac et al. Cambridge (UK): Cambridge University Press.

Hazevoet C J. 1995. The Birds of the Cape Verde Islands. Tring (UK): British Ornithologists' Union.

Hazevoet C J. 1996. Conservation and species list: taxonomic neglect promotes the extinction of endemic bird, as emplified by taxa from eastern Atlantic islands. Bird Conservation International 6: 181-196.

Hendey N I. 1964. An Introductory Account of the Smaller Algae of British Coastal Waters, Part V: Bacillariophyceae (Diatoms). London: H.M.S.O. Fisheries Investigation Series.

Hendry A P, Vamosi S M, Latham S J, Heilbuth J C, Day T. 2002. Questioning species realities. Conservation Genetics 1:67-76.

Hey J. 2001. Genes, Categories and Species. New York: Oxford University Press.

Hibbett D S, Donoghue M J. 1996. Implications of phylogenetic studies for conservation of genetic diversity in shiitake mushrooms. Conservation Biology 10:1321-1327.
Hoenen S. 1998. Comparative field ecology and morphology of two population of the troglobitic catfish Pimelodella kronei (Siluriformes: Pimelodidae) from southeastern Brazil. Papeis Avulsos de Zoologia Sao Paulo 40:324-335.

Holdaway R N, Worthy T H, Tennyson A J D. 2001. A working list of breeding bird species of the New Zealand region at first human contact. New Zealand Journal of Zoology 28:119-187.

Horvath C D. 1997. Discussion: phylogenetic species concept: pluralism, monism, and history. Biology $\mathcal{E}^{\circ}$ Philosophy 12:225-232.

Howard D J, Shields W M. 1990. Patterns of genetic variation within and among species of chauliognathus (Coleoptera: Cantharidae). Annals of the Entomological Society of America 83:326-334.

[ICBP] International Council for Bird Preservation. 1992. Putting Biodiversity on the Map: Priority Areas for Global Conservation. Cambridge (UK): International Council for Bird Preservation.

Jarman S N, Elliott N G. 2000. DNA evidence for morphological and cryptic Cenozoic speciations in the Anaspididae, 'living fossils' from the Triassic. Journal of Evolutionary Biology 13:624-633.

Jepson P, Whittaker R J. 2002. Ecoregions in context: a critique with special reference to Indonesia. Conservation Biology 16:42-57.

Jones P, Gacesa P, Butlin R. 1996. Systematics of brown planthopper and related species using nuclear and mitochondrial DNA. Pages 133-148 in The Ecology of Agricultural Pests: Biochemical Approaches, edited by W O C Symondson and J E Liddell. London: Chapman \& Hall.

Joseph L. 2000. Beginning and end of 63 years of uncertainty: the neotropical parakeets known as Pyrrhura picta and P. leucotis comprise more than two species. Proceedings of the National Academy of Sciences of Philadelphia 150:279-292.

Karl S A, Bowen B W. 1999. Evolutionary significant units versus geopolitical taxonomy: molecular systematics of an endangered sea turtle (genus Chelonia). Conservation Biology 13:990-999.

Kartesz J T. 1994. A Synonymized Checklist of the Vascular Flora of the United States, Canada, and Greenland. Second Edition. Volumes 1 and 2. Portland (OR): Timber Press.

Kasuga T, Taylor J W, White T J. 1999. Phylogenetic relationships of varieties and geographical groups of the human pathogenic fungus Histoplasma capsulatum Darling. Journal of Clinical Microbiology 37: 653-663.

King J L, Hanner R. 1998. Cryptic species in a "living fossil" lineage: taxonomic and phylogenetic relationships within the genus Lepidurus (Crustacea: Notostraca) in North America. Molecular Phylogenetics and Evolution 10:23-36.

Klautau M, Russo C A M, Lazoski C, Boury-Esnault N, 
Thorpe J P, Solé-Cava A M. 1999. Does cosmopolitanism result from overconservative systematics?: a case study using the marine sponge Chondrilla nucula. Evolution 53:1414-1422.

Knowlton N. 1993. Sibling species in the sea. Annual Review of Ecology and Systematics 24:189-216.

Knowlton N, Weigt L A. 1997. Species of marine invertebrates: a comparison of the biological and phylogenetic species concepts. Pages 199-219 in Species: The Units of Biodiversity, edited by M F Claridge, H A Dawah, and M R Wilson. London: Chapman \& Hall.

Kottelat M. 1997. European fresh water fishes: a heuristic checklist of the freshwater fishes of Europe (exclusive of the former USSR) with an introduction for non-systematists and comments on nomenclature and conservation. Biologia 52:1-271.

Koufopanou V, Burt A, Szaro T, Taylor J W. 2001. Gene genealogies, cryptic species, and molecular evolution in the human pathogen Coccidioides immitis and relatives (Ascomycota, Onygenales). Molecular Biology and Evolution 18:1246-1258.

Koufopanou V, Burt A, Taylor J W. 1997. Concordance of gene genealogies reveals reproductive isolation in the pathogenic fungus Coccidioides immitis. Proceedings of the National Academy of Sciences USA 94: 5478-5482.

Kraan S, Guiry M D. 2000. Sexual hybridization experiments and phylogenetic relationships as inferred from rubisco spacer sequences in the genus Alaria (Phaeophyceae). Journal of Phycology 36:190-198.

Kroken S, Taylor J W. 2000. Phylogenetic species, reproductive mode, and specificity of the green alga Trebouxia forming lichens with the fungal genus Letharia. Bryologist 103:645-660.

Kroken S, Taylor J W. 2001. A gene genealogical approach to recognize phylogenetic species boundaries in the lichenized fungus Letharia. Mycologia 93:38-53.

Kullander S O. 1999. Fish species-how and why. Reviews in Fish Biology and Fisheries 9:325-352.

LaGreca S. 1999. A phylogenetic evaluation of the Ramalina americana chemotype complex (Lichenized Ascomycota, Ramalinaceae) based on rDNA ITS sequence data. Bryologist 102:602-618.

Lessios H A, Kessing B D, Pearse J S. 2001. Population structure and speciation in tropical seas: global phylogeography of the sea urchin Diadema. Evolution 55:955-975.

Levin G A. 1998. Evolution in the Acalypha gracilens/ monococca complex (Euphorbiaceae): morphological analysis. Systematic Botany 23:269-287.

Mace G M, Gittleman J L, Purvis A. 2003. Preserving the tree of life. Science 300:1707-1709.

Mallet J. 2001. Concepts of species. Encyclopedia of Biodiversity 5:427-440.

Mallet J, Willmott K. 2003. Taxonomy: renaissance of
Tower of Babel? Trends in Ecology E Evolution 18: 57-59.

Mann C C, Plummer M L. 1992. The Butterfly problem. Atlantic Monthly 269(1):47-70.

Mann C C, Plummer M L. 1995. Noah's Choice. New York: Knopf.

Mayden R L. 1997. A hierarchy of species concepts: the denouement in the sage of the species problem. Pages 381-424 in Species: The Units of Biodiversity, edited by M F Claridge, H A Dawah, and M R Wilson. London: Chapman \& Hall.

Mayr E. 1942. Systematics and the Origin of Species from the Viewpoint of a Zoologist. New York: Columbia University Press.

Mayr E. 1963. Populations, Species and Evolution. Cambridge (MA): Harvard University Press.

May R M. 1990. Taxonomy as destiny. Nature 347:129130.

Medina M, Weil E, Szmant A M. 1999. Examination of the Montastraea annularis species complex (Cnidaria: Scleractinia) using ITS and COI sequences. Marine Biotechnology 1:89-97.

Metrick A, Weitzman M L. 1998. Conflicts and choices in biodiversity preservation. Journal of Economic Perspectives $12(3): 21-34$.

Mindell D P, Meyer A. 2001. Homology evolving. Trends in Ecology Eं Evolution 16:434-440.

Mishler B D. 1985. The morphological, developmental, and phylogenetic basis of species concepts in bryophytes. Bryologist 88:207-214.

Mishler B D, Budd A F. 1990. Species and evolution in clonal organisms-introduction. Systematic Botany 15:79-85.

Moulton M P, Sanderson J G. 1999. Wildlife Issues in a Changing World. Delray (Florida): St. Lucia Press.

Naeem S. 1998. Species redundancy and ecosystem reliability. Conservation Biology 12:39-45.

Nixon K C, Wheeler Q D. 1990. An amplification of the phylogenetic species concept. Cladistics 6:211223.

O’Brien S J, Mayr E. 1991. Bureaucratic mischief: recognizing endangered species and subspecies. Science 251:1187-1188.

O’Donnell K, Kistler H C, Cigelnik E, Ploetz R C. 1998. Multiple evolutionary origins of the fungus causing Panama disease of banana: concordant evidence from nuclear and mitochondrial gene genealogies. Proceedings of the National Academy of Sciences USA 95:2044-2049.

O’Donnell K, Kistler H C, Tacke B K, Casper H H. 2000. Gene genealogies reveal global phylogeographic structure and reproductive isolation among lineages of Fusarium graminearum, the fungus causing wheat scab. Proceedings of the National Academy of Sciences USA 97:7905-7910.

O’Keefe F R, Sander P M. 1999. Paleontological paradigms and inferences of phylogenetic pattern: a case study. Paleobiology 25:518-533. 
Omland K E, Tarr C L, Boarman W I, Marzluff J M, Fleischer R C. 2000. Cryptic genetic variation and paraphyly in ravens. Proceedings of the Royal Society of London B 267:2475-2482.

Owens I P F, Bennett P M. 2000. Quantifying biodiversity: a phenotypic perspective. Conservation Biology 14:1014-1022.

Packer L, Taylor J S. 1997. How many hidden species are there?: an application of the phylogenetic species concept to genetic data for some comparatively well known bee "species." Canadian Entomologist 129:587-594.

Perkins S L. 2000. Species concepts and malaria parasites: detecting a cryptic species of Plasmodium. Proceedings of the Royal Society of London B 267:23542350.

Peterson A T, Navarro-Sigüenza A G. 1999. Alternate species concepts as bases for determining priority conservation areas. Conservation Biology 13:427431.

Pitman N C A, Jorgenson P M. 2002. Estimating the size of the world's threatened flora. Science 298:989.

Platnick N I. 1999. Dimensions of biodiversity: targeting megadiverse groups. Pages 33-52 in The Living Planet: Biodiversity Science and Policy, edited by J Cracraft and F T Grifo. New York: Columbia University Press.

Puorto G, de Graça Salomão M, Theakston R D G, Thorpe R S, Warrell D A, Wüster W. 2001. Combining mitochondrial DNA sequences and morphological data to infer species boundaries: phylogeography of lanceheaded pitvipers in the Brazilian Atlantic forest, and the status of Bothrops pradoi (Squamata: Serpentes: Viperidae). Journal of Evolutionary Biology14:527-538.

Rieseberg L H, Gerber D. 1995. Hybridization in the Catalina island mountain mahogany (Cercocarpus traskiae): RAPD evidence. Conservation Biology 9: 199-203.

Rinyu E, Varga J, Ferenczy L. 1995. Phenotypic and genotypic analysis of variability in Aspergillus fumigatus. Journal of Clinical Microbiology 33(10):25672575.

Rodríguez-Robles J A, De Jesús-Escobar J M. 2000. Molecular systematics of the New World gopher, bull, and pinesnakes (Pituophis: Colubridae), a transcontinental species complex. Molecular Phylogenetics and Evolution 14:35-50.

Rojas M. 1992. The species problem and conservation: what are we protecting? Conservation Biology 6:170178 .

Rosenbaum H C, Brownell R L, Brown M W, Schaeff C, Portway V, White B N, Malik S, Pastene L A, Patenaude N J, Baker C S, Goto M, Best P B, Clapham P J, Hamilton P, Moore M, Payne R, Rowntree V, Tynan C T, Bannister J L, DeSalle R. 2000. World-wide genetic differentiation of Eubalaena: questioning the number of right whale species. Molecular Ecology 9:1793-1802.

Ryder O A. 1986. Species conservation and systematics: the dilemma of subspecies. Trends in Ecology E Evolution 1:9-10.

Sangster G. 1998. Purple swamp-hen is a complex of species. Dutch Birding 20:13-22.

Sangster G, Hazevoet C J, van den Berg A B, Roselaar C S. 1997. Dutch avifaunal list: taxonomic changes in 1977-97. Dutch Birding 19:21-28.

Schizas N V, Street G T, Coull B C, Chandler G T, Quattro J M. 1999. Molecular population structure of the marine benthic copepod Microarthridion littorale along the southeastern and Gulf coasts of the USA. Marine Biology 135:399-405.

Shank T M, Black M B, Halanych K M, Lutz R A, Vrijenhoek R C. 1999. Miocene radiation of deep-sea hydrothermal vent shrimp (Caridea: Bresiliidae): evidence from mitochondrial cytochrome oxidase subunit I. Molecular Phylogenetics and Evolution 13:244-254.

Sites J W, Jr, Crandall K A. 1997. Testing species boundaries in biodiversity studies. Conservation Biology 11:1289-1297.

Slowinski J B, Page R D M. 1999. How should species phylogenies be inferred from sequence data? Systematic Biology 48:814-825.

Small M P, Gosling E M. 2000. Species relationships and population structure of Littorina saxatilis Olivi and L. tenebrosa Montagu in Ireland using singlestrand conformational polymorphisms (SSCPs) of cytochrome $b$ fragments. Molecular Ecology 9:39-52.

Snow N. 1996. Phylogeny and systematics of Leptochloa P. Beauv. sensu lato (Poaceae, Chloridoideae) [PhD dissertation]. St. Louis (MO): Washington University.

Soltis P S, Gitzendanner M A. 1999. Molecular systematics and the conservation of rare species. Conservation Biology 13:471-483.

Spjut R W. 1996. Niebla and Vermilacinia (Ramalinaceae) from California and Baja California. Botanica Miscellany 14:1-208.

Sturmbauer C, Opadiya G B, Niederstätter H, Riedmann A, Dallinger R. 1999. Mitochondrial DNA reveals cryptic oligochaete species differing in cadmium resistance. Molecular Biology and Evolution 16:967-974.

Taylor J W, Jacobson D J, Fisher M C. 1999. The evolution of asexual fungi: reproduction, speciation and classification. Annual Review of Phytopathology 37:197-246.

Taylor J W, Jacobson D J, Kroken S, Kasuga T, Geiser D M, Hibbett D S, Fisher M C. 2000. Phylogenetic species recognition and species concepts in fungi. Fungal Genetics and Biology 31:21-32.

Templeton A R. 1989. The meaning of species and speciation: a genetic perspective. Pages 3-27 in Spe- 
ciation and its Consequences, edited by D Otte and J A Endler. Sunderland (MA): Sinauer Associates.

Thacker R W, Hadfield M G. 2000. Mitochondrial phylogeny of extant Hawaiian tree snails (Achatinellinae). Molecular Phylogenetics and Evolution 16:263270.

[USFWS] United States Fisheries and Wildlife Service. 1994. Endangered and Threatened Wildlife and Plants. Document 1994-380-789/20165. Washington (DC): U.S. Government Printing Office.

Van Roosmalen M G M, Van Roosmalen T, Mittermeier R A. 2002. A taxonomic review of the titi monkeys, genus Callicebus Thomas, 1903, with the description of two new species, Callicebus bernhardi and Callicebus stephannashi, from the Brazilian Amazonia. Neotropical Primates 10 (Supplement):152.

Van Valen L. 1976. Ecological species, multispecies, and oaks. Taxon 25:233-239.

Vilgalys R. 1991. Speciation and species concepts in the Collybia dryophila complex. Mycologia 83:758773.

Vilgalys R, Sun B L. 1994. Ancient and recent patterns of geographic speciation in the oyster mushroom Pleurotus revealed by phylogenetic analysis of ribosomal DNA sequences. Proceedings of the National Academy of Sciences USA 91:4599-4603.

Walsh P D. 2000. Sample size for the diagnosis of conservation units. Conservation Biology 14:1533-1537.

Wang J Y, Chou L-S, White B N. 1999. Mitochondrial DNA analysis of sympatric morphotypes of bottlenose dolphins (genus: Tursiops) in Chinese waters. Molecular Ecology 8:1603-1612.

Wayne R K, Gittleman J L. 1995. The problematic red wolf. Scientific American 273:26-31.

Wheeler Q D, Meier R, editors. 2000. Species Concepts and Phylogenetic Theory. New York: Columbia University Press.

Wieczorek A M, Drewes R C, Channing A. 2001. Phy- logenetic relationships within the Hyperolius viridiflavus complex (Anura: Hyperoliidae), and comments on taxonomic status. Amphibia-Reptilia 22: 155-166.

Wiens J J, Penkrot T A. 2002. Delimiting species using DNA and morphological variation in discordant spiny lizards (Sceloporus). Systematic Biology 51:6991.

Wiley E O. 1978. The evolutionary species concept reconsidered. Systematic Zoology 27:17-26.

Williams P H, Gaston K J. 1994. Measuring more of biodiversity: can higher-taxon richness predict wholesale species richness? Biological Conservation 67:211-217.

Williams S T. 2000. Species boundaries in the starfish genus Linckia. Marine Biology 136:137-148.

Wüster W, Thorpe R S. 1994. Naja siamensis, a cryptic species of venomous snake revealed by mtDNA sequencing. Experimenta 50:75-79.

Wyner Y, Absher R, Amato G, Sterling E, Stumpf R, Rumpler Y, DeSalle R. 1999. Species concept and the determination of historic gene flow patterns in the Eulemur fulvus (Brown Lemur) complex. Biological Journal of the Linnean Society 66:39-56.

Young N D. 1998. Pacific Coast Iris species delimitation using three species definitions: biological, phylogenetic and genealogical. Biological Journal of the Linnean Society 63:99-120.

Zink R M. 1994. The geography of mitochondrial DNA variation, population structure, hybridization, and species limits in the fox sparrow (Passerella iliaca). Evolution 48:96-111.

Zink R M, McKitrick M C. 1995. The debate over species concepts and its implications for ornithology. Auk 112:701-719

ZrzavýJ, Nedved O. 1997. Phylogeny of the New World Dysdercus (Insecta: Hemiptera: Pyrrhocoridae) and evolution of their colour patterns. Cladistics 13: 109-123. 